\title{
Constant flower damage caused by a common stingless bee puts survival of a threatened buzz-pollinated species at risk
}

\author{
Juliana Ordones REGO ${ }^{1}$, Reisla OLIVEIRA ${ }^{2}$, Claudia Maria $\mathrm{JACOBI}^{2}$, \\ Clemens SchlindweIN ${ }^{3}$
}

\begin{abstract}
${ }^{1}$ Programa de Pós-Graduação em Ecologia, Conservação e Manejo da Vida Silvestre, Universidade Federal de Minas Gerais, Avenida Antônio Carlos, 6627, Pampulha, Belo Horizonte 31270-901, Brazil

${ }^{2}$ Departamento de Biologia Geral, Universidade Federal de Minas Gerais, Avenida Antônio Carlos, 6627, Pampulha, Belo Horizonte 31270-901, Brazil

${ }^{3}$ Departamento de Botânica, Universidade Federal de Minas Gerais, Av. Antônio Carlos, 6627, Belo Horizonte 31270 910, Brazil
\end{abstract}

Received 3 May 2017 - Revised 13 September 2017 - Accepted 2 October 2017

\begin{abstract}
Illegitimate flower visitors may reduce the reproductive success of their host plants. Eriocnema fulva, a threatened Melastomataceae of the Atlantic Forest, Brazil, has pollen flowers with poricidal anthers that show frequent damage of floral parts. We identified the flower-damaging bees and determined their impact on fruit set. Bees of seven species visited their flowers, but only three species collected pollen by vibration. With only one visit to a flower patch per $12 \mathrm{~h}$, the frequency of effective buzz pollinating bees was negligible, while flower-damaging workers of the stingless bee Trigona fulviventris (Apidae) accounted for $70 \%$ of the visits. During their lengthy visits, they cut anthers to access pollen, and often styles as well. We conclude that the direct negative consequence of flower damage by Trigona bees, as well as their indirect impact by making the flowers unattractive for effective pollinators is a major reason for the low fruit set (6.9\%) of E. fulva. Considering the rareness of the plant species, these negative effects put the survival of $E$. fulva at risk.
\end{abstract}

\section{destructive flower visits / Meliponini / pollen robbers / reproductive success / Trigona}

\section{INTRODUCTION}

Plant species that are threatened with extinction usually occur in small, sparse populations in fragmented and specialized habitats under negative anthropic impacts. Knowledge of the reproductive biology of rare or threatened plants, especially regarding factors that limit sexual reproduction, is fundamental for their conservation (Kruckeberg and Rabinowitz 1985; Evans et al. 2003). Pollination limitation is expected to be more accentuated in these species due to the scarcity of reproductive partners, greater distances between in-

Corresponding author: C. Schlindwein, schlindw@gmail.com

Manuscript editor: James Nieh dividual plants, and reduction of pollinator abundance due to the lower availability of floral resources (Potts et al. 2004; Roulston and Goodell 2011).

Factors that limit pollination in common and rare species may be related to pollen loss to the environment or to pollen consumers (Schlindwein et al. 2005), florivory (Ferreira and TorezanSilingardi 2013), lack of pollinators, or poor efficiency of floral visitors (Kearns et al. 1998; Wilcock and Neiland 2002). Herbivores that feed on flowers affect the reproductive success of plants by reducing the availability of pollen, ovules, and pistils (Krupnick et al. 1999; Canela and Sazima 2003).

Among bees, workers of genus Trigona (Apidae, Meliponini) are known to damage flowers of several plant species when they collect pollen or nectar (Renner 1983; 
Gottsberger and Silberbauer-Gottsberger 1988; Tezuka and Maeta 1995). It has been demonstrated that in some cases, this damage has reduced the plants' reproductive success (Sazima and Sazima 1989; Milet-Pinheiro and Schlindwein 2009; Schlindwein et al. 2014). Worker bees of Trigona damage flowers because they cannot reach hidden nectar resources due to their short mouthparts or because they cannot collect pollen legitimately in flowers with poricidal anthers. In these anthers, pollen grains are hidden and released by apical pores only after vibration of the anthers by female bees (buzz pollination; Buchmann 1983; Fracasso and Sazima 2004; Nunes-Silva et al. 2010; De Luca and VallejoMarín 2013; Burkart et al. 2014). This mechanism diminishes pollen loss to the environment and opportunistic consumers and favors the effective pollinating buzz pollinators (Endress 1994).

In species with poricidal anthers, such as representatives of Melastomataceae and Cassiinae (Fabaceae), workers of Trigona, who do not vibrate flowers to collect pollen (Buchmann 1983; De Luca and Vallejo-Marín 2013; Mesquita-Neto et al. 2017), harm anthers while obtaining access to pollen (Wille-Trejos 1963; Renner 1983; Gottsberger and SilberbauerGottsberger 1988). However, the impact that this damage has on the reproductive success of these species has not been assessed even though it would be particularly relevant for plant species that are threatened with extinction.

Eriocnema fulva Naudin (Melastomataceae) is a rare, threatened species with poricidal anthers, classified as "Vulnerable" in the Brazilian list of threatened species (MMA 2014). There are records of only four populations, all with distribution restricted to rocky cliffs close to small water bodies in the Quadrilátero Ferrífero (Iron Quadrangle) (Andrade 2009), a region in southeast Brazil under heavy anthropogenic impact derived from iron ore mining (Jacobi and do Carmo 2008; Jacobi et al. 2011). Studies on the floral biology of E. fulva have detected frequent damage to its flowers (Andrade et al. 2007a).

Focusing on the effect of flower damage on fruit development of this threatened species, we ask: who are the floral visitors of E. fulva and who among them cause damage to floral tissues? Which flower parts are damaged and at what rate? What are the effects of floral damage on fruit set?

\section{MATERIALS AND METHODS}

\subsection{Study area}

The study was conducted during three flowering seasons of E. fulva (November to February) between 2013 and 2016. Data collection was more intense in the flowering season of $2013 / 2014$ and 2014/2015, with about seven non-consecutive days per month. The studied population was located within an environmental protection area south of the Belo Horizonte Metropolitan Region (APA-Sul $\mathrm{RMBH}$ ), at $20^{\circ} 08^{\prime} 17.3^{\prime \prime} \mathrm{S}, 43^{\circ} 47^{\prime} 34.6^{\prime \prime}$ $\mathrm{W}$, and $753 \mathrm{~m}$ altitude, in the state of Minas Gerais, Brazil.

This protected area is situated within the Quadrilátero Ferrífero (Iron Quadrangle) of the southern Espinhaço Mountain Range, which is one of the most diverse regions of Brazil as well as a center of endemism for several plant groups (Giulietti et al. 1997). The Quadrilátero Ferrífero lies in the transition zone between the Atlantic Forest and the Cerrado, two global biodiversity hotspots (Myers et al. 2000). Its rocky outcrops cover important iron ore deposits and are thus directly exposed to irreversible interventions of great magnitude in the form of opencast mining, creating a situation that puts the associated biota at immediate risk (Jacobi and do Carmo 2008; Jacobi et al. 2011). Due to the great number of endemic plants and the constant pressure from mining, urban expansion, and wildfires, the Quadrilátero Ferrífero was included among the Priorities for Biodiversity Conservation of the state of Minas Gerais (Drummond et al. 2005).

The climate of the region is characterized by humid summers with heavy rainfalls (November to February) and drier mild winters. Annual mean temperature is $21^{\circ} \mathrm{C}$, and mean annual precipitation is $1500 \mathrm{~mm}$ (Ramos et al. 2009). 


\subsection{Study species}

Eriocnema fulva is a perennial herb with simple or bifurcated stems, opposite pilose leaves, and red-pilose petioles. The flowers have a diameter of $10 \mathrm{~mm}$, five white petals and ten stamens of $5 \mathrm{~mm}$ in length with poricidal anthers. The pistil has a style somewhat longer than the stamens with a small and poorly delimited stigma. The species is self-compatible but does not produce fruits by spontaneous self-pollination (Andrade et al. 2007a). Fruit set after crosspollination was about 3-fold when compared to geitonogamous pollination in that population, and the plants suffered pollinator limitation. We focused our study on the population that occurs on steep, rocky, humid, and shadowy slopes at the margins of the "Das Velhas" river along an unpaved road. This population contains about 50 individuals in an area of roughly $300 \mathrm{~m}^{2}$ and is surrounded by closed species-rich secondary Atlantic Forest. The habitat of the river slopes is composed of few species co-flowering with Eriocnema fulva, such as shrubs and herbs of Anetanthus gracilis Hiern (Gesneriaceae), Manettia pubescens Cham. \& Schltdl. (Rubiaceae) Manihot sp. (Euphorbiaceae), Pombalia setigera (A.St.-Hil.) Paula-Souza (Violaceae), Psychotria sp. (Rubiaceae), and Stemodia microphylla J.A.Schmidt (Plantaginaceae).

\subsection{Floral biology}

The number of inflorescences, flowers/inflorescence, and seeds/fruit were determined for 11 tagged plants. Anthesis duration, anther dehiscence, and floral longevity were determined in 20 flowers from different plants. We monitored 119 individually marked flowers from ca. 35 plants to characterize color changes of the different floral parts throughout anthesis.

To calculate the pollen/ovule ratio, the number of pollen grains per flower was assessed with a Neubauer chamber. For this, we fixed 20 pre-anthesis buds from different individuals in ethanol $70 \%$. The stamens of each bud were placed in Eppendorf tubes containing a solution of $0.5 \mathrm{~mL}$ lactic acid and glycerin at 3:1. They were then macerated and agitated for $2 \mathrm{~min}$ in a vortex agitator. An aliquot was then transferred to the Neubauer chamber, and the pollen grains were counted to estimate the total number of pollen grains per flower (Dafni et al. 2005). In the same buds, we counted the ovules under a stereomicroscope and then calculated the pollen/ovule ratio.

Voucher specimens were deposited in the herbaria of Universidade Federal de Minas Gerais (BHCB 180801) and Jardim Botânico da Fundação Zoo-Botânica de Belo Horizonte (BHZB 10404).

\subsection{Floral visitors}

The frequency of floral visitors was determined from a total of $63 \mathrm{~h}$ of continuous field observations made between 0800 hours and 1700 hours during non-consecutive days, between December and January, in the flowering season of 2013/20014 (4 days) and 2014/2015 (3 days). Continuous observations were done in focal patches $\left(1-2 \mathrm{~m}^{2}\right)$ of the population where there were the most open flowers each day (ca. 45-50) due to the scarcity of floral visitors. We recorded the time and length of visits and classified the pollen-gathering behavior as follows: (1) bees that vibrate anthers, (2) bees that gather pollen from the surface of petals and stamens, and (3) bees that gather pollen by cutting anthers. Floral visitors were collected and deposited in the Entomological Collection of UFMG (Centro de Coleções Taxonômicas da UFMG, Universidade Federal de Minas Gerais, Belo Horizonte, Brazil).

\subsection{Floral damage}

We characterized the behavior of bees that damaged flowers according to the duration of visit, damage to style, and number of anthers damaged. Bees were filmed and photographed.

To determine the degree of floral damage at different stages of anthesis, we labeled flowers individually in 2014 and 2015 and quantified: (1) the percentage of anthers and styles damaged ( $N=109,2014 ; N=140,2015)$; (2) the stage of anthesis at which the damage occurred $(N=109$, 2014); (3) the fruiting rate of damaged and intact flowers $(N=109,2014 ; N=140,2015)$; and (4) 
the number of seeds per fruit formed. Fruits were collected 2 months after anthesis. To determine the stage of anthesis at which the flowers were damaged we recorded the color of filaments, styles, and the base of petals on a daily basis.

To evaluate the constancy of flower damage by Trigona bees to the population, we counted the number of damaged anthers and styles during 4 weeks in the season flowering peak, between December 2014 and January 2015, in 70 flowers per week.

\subsection{Statistical analyses}

We used a general linear model (GLM) with quasipoisson distributed errors and a log link function to compare the number of anthers damaged in each of the four consecutive weeks, and a GLM with binomial distributed errors and a logit link function to compare the occurrence of damage on styles. We compared the number of seeds produced by style-damaged and styleundamaged flowers using a GLM with binomial negative distribution, and log function.

We used logistic regression (Agresti 2007) to analyze the effects of anther and style damage on fruit set. We calculated a logit link function with fruit set as binary response variable $(1=$ fruit production; $0=$ no fruit production). The independent variables were number of damaged anthers (0-10 anthers) and damage to style (coded as binary; 0 = damage; $1=$ no damage). We computed a complete model with both independent variables and the interaction included. As the interaction between damage to anther and style had no significant effect on fruit set, we simplified the model removing the interaction. All analyses were computed with R package "Stats" version 3.3.1 (R Core Team 2015).

\section{RESULTS}

\subsection{Floral biology}

Eriocnema fulva bloomed from November to January, and the fruits released seeds from February to June. Individuals produced an average of 4.4 $(\mathrm{SD}=3.3$; range $=1-11 ; N=11)$ inflorescences, and each of these developed 2.9 (SD = 1.7; range $=1-7 ; N=48$ ) flowers. A total of 41 buds (22.6\%, $N=181)$ were aborted. Individuals produced an average of $2.3(\mathrm{SD}=2.8 ;$ range $=0$ $8 ; N=11)$ fruits $(N=20)$ with $130.6 \pm 46.2$ seeds, measuring approximately $2 \mathrm{~mm}$ in length.

Flowers opened throughout the day, between 0800 hours and 1700 hours. The style was already erect when the petals spread. The stamens remained folded with the apex of the anthers hidden towards the base (Fig. 1a). About 30$40 \mathrm{~min}$ after onset of anthesis, the stamens unfolded to their final position, with the apical pores already open (Fig. 1b).

Flowers lasted 4-5 days. At the start of anthesis, the petals were white with yellow bases, and the filaments and styles were yellow. On the second and third days, the yellow petal bases, filaments, and styles changed gradually to orange and orange-red, and to completely red on the fourth day (Fig. 1c). Stamens and petals began to fall on the fourth day. Each flower $(N=20)$ produced $77,262 \pm 38,802$ pollen grains and $248 \pm 53.5$ ovules. The pollen/ovule ratio was 328:1.

\subsection{Floral visitors}

Females of six bee species visited the flowers of E. fulva: three Augochlorini (Halictidae), two stingless bees (Apidae, Meliponini), and one Ceratina (Apidae, Ceratinini), all small to minute in size (Table I). Only females of Augochloropsis collected pollen by vibration. They vibrated the anthers individually and were the only visitors that contacted the stigma. Workers of the stingless bee Tetragonisca angustula and females of Ceratina (Ceratinula) sp., both with minute body sizes, gathered pollen grains from the surface of petals, anthers, and filaments after vibration-buzzing by the other species. Workers of T. fulviventris cut the anthers to obtain pollen.

Floral visitors were extraordinarily rare: throughout the entire $63 \mathrm{~h}$ of observation in focal patches of 45-50 flowers only 46 bees were recorded. Augochloropsis appeared exclusively in the afternoon (1200 hours-1700 hours), Tetragonisca angustula and Ceratina in the late morning and in the afternoon (1100 hours-1500 


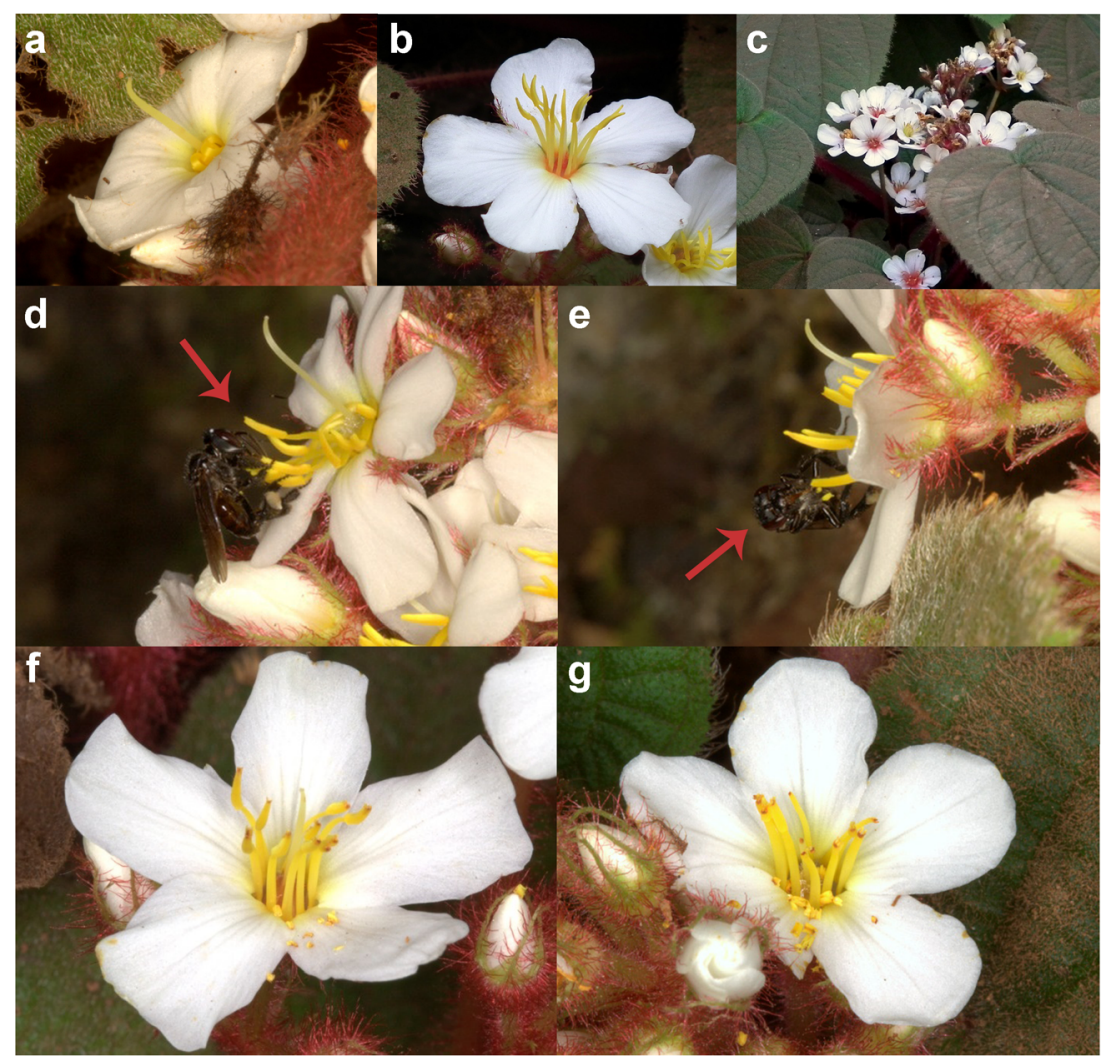

Figure 1. Flowers of Eriocnema fulva throughout anthesis $(\mathbf{a}-\mathbf{c})$. a Freshly opened flowers with anthers still hidden, oriented towards the base of the flower; base of petals and entire styles yellow. $\mathbf{b}$ Flower at the end of the first day of anthesis with the stamens unfolded; base of petals yellow, bases of filaments and styles orange; the flower to the right just after flower opening with the unfolding stamens. $\mathbf{c}$ Inflorescence with several open flowers, most at the end of anthesis with petal bases, filaments and styles red. Pollen collection by a worker Trigona fulviventris in a freshly opened flower and flower damage $(\mathbf{d}-\mathbf{g})$. d Insertion of mouth parts into an anther to collect pollen. e Worker cutting an anther; most of the anthers of this flower have already been partially cut, style with stigma still intact. f Flower with partially cut anthers; the cut slices fallen on the petals. $g$ Flowers with cut anthers and style.

hours), and workers of $T$. fulviventris, the most frequent visitors, appeared throughout the entire day.

\subsection{Floral damage}

To collect pollen, the worker bees of T. fulviventris inserted their glossa and labial palpi into the anther pore (Fig. 1d), withdrew the mouthparts and removed the adhering pollen grains with their front legs and placed them on the ventral part of the thorax. After several transfers of pollen grains to the thorax, they moved the accumulated pollen with their mid-legs to the corbiculae on the hind tibia. They repeatedly made transverse cuts with their mandibles (Fig. 1e) to reach the pollen grains located deeper within the anther. The cut anther slices frequently dropped and accumulated at the petal bases (Fig. 1f, g). After each cut, the bees reintroduced the mouthparts into the cut anthers. The worker bees collected pollen from the different anthers in a uniform manner. In addition to anthers, they also frequently cut filaments and styles (Fig. 1g).

When workers of $T$. fulviventris arrived at a flower patch with an empty scopa, they usually visited 3-4 flowers to collect pollen. They remained on the flowers for an average of $185 \mathrm{~s}(\mathrm{SD}=145$, range $20-635, N=23)$, 
Table I. Flower visitors of Eriocnema fulva during three flowering seasons (2013-2016)

\begin{tabular}{|c|c|c|c|c|}
\hline Floral visitors & Sex & Pollen collection & Body length (mm) & Stigma contact \\
\hline \multicolumn{5}{|l|}{ Apidae } \\
\hline \multicolumn{5}{|l|}{ Ceratinini } \\
\hline Ceratina (Ceratinula) sp. & q & Gleaning & $4.0-4.3$ & No \\
\hline \multicolumn{5}{|l|}{ Meliponini } \\
\hline Tetragonisca angustula (Latreille, 1811) & q & Gleaning & $3.6-3.8$ & No \\
\hline Trigona fulviventris Guérin 1844 & q & Anther cutting & $6.4-6.7$ & Occasionally \\
\hline \multicolumn{5}{|l|}{ Halictidae } \\
\hline \multicolumn{5}{|l|}{ Augochlorini } \\
\hline Augochloropsis sp.1 & q & Buzzing & $6.0-6.3$ & Yes \\
\hline Augochloropsis sp. 2 & q & Buzzing & $6.1-6.3$ & Yes \\
\hline Augochloropsis sp.3 & q & Buzzing & $7.0-7.3$ & Yes \\
\hline
\end{tabular}

and took $47 \pm 26 \mathrm{~s}$ to collect pollen from each anther (range 28-103, $N=11$ ). This period corresponds to one, two, or three pollen gatherings separated by one or two cuts to the same anther.

Flower damage by $T$. fulviventris occurred mainly on the first day of anthesis, when filaments, petal bases, and styles were still yellow. On the first day of anthesis, $81.5 \%$ of the anthers and $61.1 \%$ of the styles were damaged $(N=109$ flowers). At the end of anthesis, $98.3 \%$ of the flowers showed anther damage and $76.9 \%$ style damage in 2 years of observation $(N=280)$. Most flowers had damage to all ten stamens by the end of anthesis: $92.4 \%$ of flowers in $2015(N=109)$ and $82.5 \%$ in $2016(N=280)$.

Flower damage occurred continuously during the peak flowering of E. fulva. In the first 2 weeks of monitoring, anther and style damage was more intense ( 9.8 anthers damaged per flower) than in the two subsequent weeks (8.9 anthers damaged) (GLM with quasipoisson error $F=6.931$; $d f$ $=276 ; P<0.001$; for style damage-GLM with binomial error $\chi^{2}=9.850 ; d f=276 ; P=0.019$ ). The percentage of damaged styles varied between 53 and $76 \%$ during the period.

\subsection{Effect of floral damage on fruit set}

In the 2 years of observation fruit set was $6.5 \%(2013 / 2014 ; N=92$ flowers $)$ and $7.1 \%$
(2014/2015; $N=140$ flowers). The logistic regression model showed that damage on the style significantly reduced the probability of E. fulva setting fruit. The chances of a flower setting fruit decreased 4-fold when the style was damaged $(3.9 \%, 7 / 176)$ and $16 \%$ $(9 /=56)$ in flowers without damage (Table II; Fig. 2).

The average seed number in fruits resulting from flowers with damaged anthers only $(145.7 \pm 70.86, N=6)$ did not differ significantly from that with both style and anthers damaged $(131.4 \pm 71.54, N=6$; GLM with binomial error $\left.\chi^{2}=0.142 ; d f=10 ; P=0.706\right)$.

\section{DISCUSSION}

The individuals of Eriocnema fulva had a constant, very low fruit set rate throughout two reproductive seasons. Considering the rarity of the plant species due to habitat loss (Baumgratz et al. 2013), this low fruit set caused by floral damages of Trigona fulviventris is critical for the survival of the species. Visits by this bee reduced fecundity directly by removing anthers and stigma, and indirectly by consuming pollen, which would otherwise be available for effective pollinators. This pollen loss also reduces the potential for these flowers to serve as pollen donors, thereby reducing the male component of fitness. 
Table II. Summary of logistic regression models explaining the effects of damage on anthers and styles on the probability of Eriocnema fulva flowers to set fruit $(N=232)$

\begin{tabular}{|c|c|c|c|c|c|}
\hline Variables in the model & AIC & $\beta \pm \mathrm{SE}$ & $Z$ & $P$ & $\operatorname{Exp}(\beta)$ \\
\hline \multicolumn{6}{|l|}{ Fruit set } \\
\hline Model 1 & 114.9 & & & & \\
\hline Intercept & & $-0.599 \pm 0.912$ & -0.657 & 0.511 & 0.549 \\
\hline Anthers & & $-0.129 \pm 0.107$ & -1.208 & 0.227 & 0.879 \\
\hline Style & & $-2.653 \pm 4.586$ & -0.578 & 0.563 & 0.070 \\
\hline Anthers/style & & $0.136 \pm 0.467$ & 0.291 & 0.771 & 1.145 \\
\hline Model 2 & 113 & & & & \\
\hline Intercept & & $-0.6798 \pm 0.881$ & -0.771 & 0.441 & 0.506 \\
\hline Anthers & & $-0.119 \pm 0.102$ & -1.166 & 0.243 & 0.888 \\
\hline Style & & $-1.341 \pm 0.566$ & -2.368 & $0.018^{*}$ & 0.262 \\
\hline
\end{tabular}

*Significant at $5 \%$

\subsection{Direct negative effect of Trigona on fruit production of $E$. fulva}

Workers of several species of Trigona, bees widely distributed throughout Central and South America, are known as detrimental floral visitors because they destroy flowers, rob nectar, and/or defend floral resources against other bee species. During pollen larceny, they usually cut anthers and styles with the mandibles, with direct negative effects on the reproductive success and fitness of the plants that provide pollen resources (Sazima and Sazima 1989; Milet-Pinheiro and Schlindwein
2009; Schlindwein et al. 2014). Unable to access pollen legitimately via vibration, workers of T. fulviventris not only cut the anthers but also cut the styles in $75 \%$ of the flowers of E. fulva they damage. In this way, they directly affect ovule fecundity by precluding pollen germination in the stigma or pollen-tube growth in the style. When fruit set in styles with damaged stigmata occurred, Trigona workers presumably cut the style after pollen tubes had already reached the ovary. Usually, this happens in less than $24 \mathrm{~h}$ after pollen deposition in Melastomataceae (Santos et al. 2012). Fruit set was low in flowers with cut styles as well as with intact stigma but with cut anthers. This

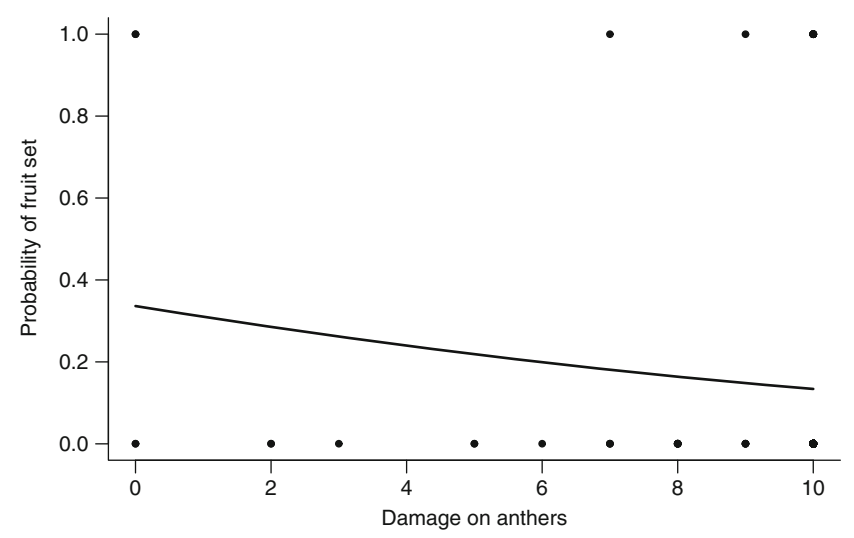

Figure 2. Predicted fruit set per flower of Eriocnema fulva, calculated from logistic regressions, after damage on none to all anthers. 
demonstrates that workers of T. fulviventris do not even contribute to flower self-pollination in E. fulva.

\subsection{Indirect negative effect of Trigona on fruit production of $E$. fulva}

Despite the slow and harmful pollen gathering performed by workers of Trigona, they could have efficiently removed almost all the pollen resource produced by the population of E. fulva, when taken into account damage rates $(98 \%)$ and the relative abundance of floral visits $(70 \%)$. This permanent low availability of pollen in the flowers might have discouraged floral visits by effective pollinators. During $12 \mathrm{~h}$, on average, only one single pollinating/ vibrating bee (Augochloropsis sp.) was recorded on flowers of $E$. fulva .

Removal of pollen that involves damage to floral parts by workers of Trigona lasts much longer (up to more than $10 \mathrm{~min}$ ) than visits of bees that handle flowers legitimately (Renner 1983; De Luca and Vallejo-Marín 2013; Schlindwein et al. 2014), because the worker bees must spend time chewing floral tissues and making consecutive cuts associated with removal of tiny amounts of floral resources to get nourishment. Bees that vibrate flowers take only one to few seconds to remove pollen (De Luca et al. 2013) making them effective pollinators that busily move between conspecific plants.

Asynchronous flower opening makes it difficult for resource-seeking effective pollinators to adjust their visits to the period when E. fulva offers pollen. When a population is large enough, asynchronous flowering within individuals promotes outcrossing by forcing pollinators to move between plants (Stephenson 1982; Schmitt 1983; Rathcke and Lacey 1985; Ims 1990). The opposite effect occurs when populations are very small and undergo pollen theft like the studied population. In E. fulva, this could have also contributed to the extraordinary scarcity of effective pollinators. In Gongora quinquenervis, an orchid species with short non-synchronized flowering phases of individuals, reproductive success was shown to be extraordinarily low in a small population, even without thefts (Martini et al. 2003).

Besides the negative effects of flowerdamaging Trigona bees on the fruit set, the overall low pollen amount of the flowers of E. fulva might have intensified the reduction of attractiveness of E. fulva flowers to pollinators. The flowers of $E$. fulva carry few pollen grains (a mean of 77,262) when compared to other Melastomataceae species (e.g., Tococa nitens, 579,100; Comolia microphylla, 124,440; Tibouchina fraterna, 537,292) (Hokche and Ramirez 2008), expressed in a low pollen/ovule ratio, and thus might be less attractive to pollen collecting buzz-pollinating bees than the more pollen rich flowers.

Species of Melastomataceae usually produce fruits at much higher rates (35-91.5\%) (Fracasso and Sazima 2004; Fracasso 2008; Santos et al. 2010) than what we found in our study. The combination of scarce resources and damaging negative effects may have discouraged visits by effective pollinators, which are those that can buzz pollinate.

Trigona bees are known to damage anthers to collect pollen hidden in poricidal anthers of Melastomataceae, Cassiinae and Solanum (Renner 1983; Gottsberger and SilberbauerGottsberger 1988; Bezerra and Machado 2003). Renner (1983) described in detail the destructive behavior of pollen gathering by workers of Trigona dallatorreana, T. fulviventris, T. hyalinata, T. spinipes, and T. williana to flowers of 34 species of Melastomataceae. The different species of Trigona show similar behavior, and our study corroborates that of Renner (1983). Besides the cuts in anthers cited in the works above, workers of T. fulviventris also cut the styles in the studied E. fulva population, intensifying the negative effect on fruit set. In contrast to the studies that show species of Trigona as floral visitors that cause a negative impact on the reproductive success, there are some cases in which they may be effective pollinators (Slaa et al. 2006; Silberbauer-Gottsberger et al. 2013; Pinto and Schlindwein 2014, Giannini et al. 
2014) or secondary pollinators (Stein and Hensen 2011). Recently, the label rescue pollinator was proposed for the very common $T$. spinipes due to its capacity to colonize degraded habitats and its persistence in heavily altered landscapes (Jaffé et al. 2016). However, because of the numerous reports on the negative impacts on pollination and fruit set, which bees of Trigona cause in many plant species they visit, the term appears to be misapplied.

\subsection{Self-compatibility does not save $E$. fulva}

Failure of pollination due to lack of effective pollinators or scarcity of floral visitors, for example in regions with adverse climatic conditions, may be compensated by self-pollination in selfcompatible species (Wilcock and Neiland 2002; Vaughton and Ramsey 2010; Rodger et al. 2013). This is not the case for the self-compatible E. fulva because the pollen grains, hidden inside the poricidal anthers, do not reach the stigma without the mediation of bees that vibrate the flowers.

Eriocnema fulva is a threatened species, with only four small known populations in a region with constant pressure of opencast mining activities (Jacobi and do Carmo 2008; Jacobi et al. 2011). The studied population was chosen because of the highest density of individuals and easy access. The other three populations had signs of flower damage and in one of them Andrade et al. (2007a, b) also observed the destruction of stamens by Trigona sp.

We therefore conclude that direct and indirect negative impacts of damage to anthers and styles inflicted by Trigona fulviventris negatively affect the reproductive success of Eriocnema fulva and put its survival at risk. The conservation of this threatened species, regarding its in situ reproduction, requires measures against general habitat loss that will benefit both abundance of this plant species and of its effective pollinators. Ex situ conservation measures should also be implemented, such as keeping specimens in botanical collections to enable its reproduction and reintroduction. Measures against the flower-damaging native stingless bees, however, are not an option due to the numerous biological interactions that these bees show with the native flora and fauna.

\section{ACKNOWLEDGEMENTS}

We thank Carlos Alberto Ferreira Junior for his help during field work; José Neiva, Alberto Teixido, and Paula Calaça for their help with the statistical analyses and discussion; and David Inouye and two anonymous reviewers for their comments, which improved the manuscript. The Fundação Zoo-Botânica provided logistic support. The support of the graduate course in Ecology, Conservation and Management of Wildlife (ECMVS), Universidade Federal de Minas Gerais, is duly acknowledged. We also thank for the individual research fellowships from Coordenação de Aperfeiçoamento de Pessoal de Nível Superior (PNPD-CAPES) to RO, and from Conselho Nacional de Desenvolvimento Científico e Tecnológico (CNPq) to CMJ and CS.

Contributions JOR, CS conceived research, designed experiments; RO, CMJ design, interpretation of data; JOR performed experiments; JOR, CS wrote the paper. All authors read and approved the final manuscript.

\section{FUNDING INFORMATION}

This research received financial support from Fundação de Amparo à Pesquisa do Estado de Minas Gerais (FAPEMIG), Processo APQ01707-14.

\section{COMPLIANCE WITH ETHICAL STANDARDS}

Conflict of interest The authors declare that they have no conflict of interest.

Les dégâts continuels causés à la fleur par une espèce commune d'abeille sans aiguillon compromettent la survie d'une plante menacée pollinisée par vibration

dégât floral / visite de la fleur / Meliponini / voleur de pollen / succès reproductif / Trigona

Kontinuierliche Schädigungen von Blüten durch eine weitverbreitete stachellose Biene gefährdet das Überleben einer vibrationsbestäubten bedrohten Art

destruktive Blütenbesuche / Meliponini / Pollendiebe / Reproduktionserfolg / Trigona 


\section{REFERENCES}

Agresti, A. (2007) Logistic Regression, in: An introduction to categorical data analysis, Second Edition, John Wiley, Sons, Inc., Hoboken, NJ, USA. https://doi. org/10.1002/9780470114759.ch4

Andrade, P.M. (2009) Sistema de reprodução e recomendações para conservação da Eriocnema fulva Naudin (Melastomataceae), espécie ameaçada de extinção. Biota 2 (1), 4-31

Andrade, P.M., Forni-Martins, E.R., Martins, F.R. (2007a) Reproductive system of Eriocnema fulva Naudin (Melastomataceae), an endemic species of Minas Gerais state, SE Brazil. Braz. J. Biol. 67 (2), 313-319

Andrade, P.M., Santos, F.A.M., Martins, F.R. (2007b) Size structure and fertility in an Eriocnema fulva Naudin (Melastomataceae) population in Southeastern Brazil. Braz. J. Biol. 67 (4), 685-693

Baumgratz, J.F.A., Pinheiro, F.M., Santos, L.A.F., Barros, F.S.M., Sfair, J.C., Moraes, M.A., Messina, T. (2013) Melastomataceae, in: Martinelli, G., Moraes, M.A. (Eds.), Livro vermelho da flora do Brasil. Instituto de Pesquisas Jardim Botânico do Rio de Janeiro, Rio de Janeiro, pp. 673-696

Bezerra, E.L.S., Machado, I.C. (2003) Biologia floral e sistema de polinizacão de Solanum stramonifolium Jacq. (Solanaceae) em remanescente de Mata Atlântica, Pernambuco. Acta Botanica Brasilica 17, 247-257

Buchmann, S.L. (1983) Buzz pollination in angiosperms, in: C.E. Jones, R.J. Little (Eds.), Handbook of experimental pollination biology. Van Nostrand, Reinhold, New York, pp. 73-113

Burkart, A., Schlindwein, C., Lunau, K. (2014) Assessment of pollen reward and pollen availability in Solanum stramoniifolium and Solanum paniculatum for buzzpollinating carpenter bees. Plant Biol. 16, 503-507

Canela, M.B.F., Sazima, M. (2003) Florivory by the crab Armases angustipes (Grapsidae) influences hummingbird visits to Aechmea pectinata (Bromeliaceae). Biotropica 35, 289-294

Dafni, A., Kevan, P.G., Husband, B.C. (2005) Practical Pollination Ecology. Enviroquest, Cambridge, Canada

De Luca, P.A., Vallejo-Marín, M. (2013) What's the "buzz" about? The ecology and evolutionary significance of buzz-pollination. Curr. Opin. Plant Biol. 16, 429-435

De Luca, P. A., L. F. Bussiere, D. Souto-Vilaros, D. Goulson, A. C. Mason, M. Vallejo-Marín (2013). Variability in bumblebee pollination buzzes affects the quantity of pollen released from flowers. Oecologia 172, 805-816

Drummond, G.M., Martins, C.S., Machado, A.B.M., Sebaio, F.A., Antonini, Y. (2005) Biodiversidade em Minas Gerais: um atlas para sua conservação. Belo Horizonte, Fundação Biodiversitas, 222p

Endress, P. K. (1994) Diversity and evolutionary biology of tropical flowers. Cambridge University Press, Cambridge
Evans, M.E.K., Menges, E.C., Gordon, D.R. (2003) Reproductive biology of three sympatric endangered plants endemic to Florida scrub. Biol. Conserv. 111 , 235-246

Ferreira, C.A., Torezan-Silingardi, H.M. (2013) Implications of the floral herbivory on Malpighiaceae plant fitness: visual aspect of the flower affects the attractiveness to pollinators. Sociobiology 60 (3), 323-328

Fracasso, C.M. (2008) Biologia da Polinização e reprodução de espécies de Melastomataceae do Parque Nacional da Serra da Canastra, Minas Gerais. Tese de doutorado, Universidade Estadual de Campinas

Fracasso, C.A., Sazima, M. (2004). Polinização de Cambessedesia hilariana (Kunth) D.C. (Melastomataceae): sucesso reprodutivo versus diversidade, comportamento e frequência de visitas de abelhas. Rev. Bras. Bot. 27 (4), 797-804

Giannini, T.C., Boff, S., Cordeiro, G.D., Cartolano, Jr. E.A., Veiga, A.K., Imperatriz-Fonseca, V.L., Saraiva, A.M. (2014) Crop pollinators in Brazil: a review of reported interactions. Apidologie 46, 209-223

Giulietti, A.M., Pirani, J.R., Harley, R.M. (1997) Espinhaço range region, in: Davis, S.D., Heywood, V.H., HerreraMacBride, O., Villa-Lobos, J., Hamilton, A.C. (Eds.), Centres of plant diversity, vol. 3. The Americas. WWF-IUCN, Washington, 397-404

Gottsberger, G., Silberbauer-Gottsberger, I. (1988) Evolution of flower structure and pollination in Neotropical Cassinae (Caesalpiniaceae) species. Phyton (Austria) 28, 293-320

Hokche, O.D., Ramirez, N. (2008) Sistemas reproductivos em especies de Melastomataceae en La Gran Sabana (Estado Bolívar, Venezuela). Acta Bot. Venezuela 31, $387-408$

Ims, R. A. (1990) The ecology and evolution of reproductive synchrony. Trends Ecol. Evol. 5, 135-140

Jacobi, C.M., do Carmo, F.F. (2008) The Contribution of Ironstone Outcrops to Plant Diversity in the Iron Quadrangle, a threatened Brazilian landscape. Ambio (Oslo) 37, 324-326

Jacobi, C.M., do Carmo, F.F., Campos, I.C. (2011) Soaring extinction threats to endemic plants in Brazilian metalrich regions. Ambio (Oslo) 40, 540-543

Jaffé, R., Castilla, A., Pope, N., Imperatriz-Fonseca, V.L., Metzger, J.P., Arias, M.C., Jha, S. (2016) Landscape genetics of a tropical rescue pollinator. Conserv. Genet. 17, 267-278

Kearns, C.A., Inouye, D.W., Waser, N.W. (1998) Endangered mutualisms: the conservation of plant-pollinator interactions. Annu. Rev. Ecol. Syst. 29, 83-112

Kruckeberg, A.R., Rabinowitz, D. (1985) Biological aspects of endemism in higher plants. Annu. Rev. Ecol. Syst. 16, 447-479

Krupnick, G.A., Weis, A.E., Campbell, D.R. (1999) The consequences of floral herbivory for pollinator service to Isomeris arborea. Ecology 80 (1), 125-134

Martini, P., Schlindwein, C., Montenegro, A. (2003) Pollination, flower longevity and reproductive biology of Gongora quinquenervis Ruíz and Pavón 
(Orchidaceae) in an Atlantic Forest fragment of Pernambuco, Brazil. Plant Biol. 5, 495-503

Mesquita-Neto, J.N., Costa, B.P. Schlindwein C. (2017). Heteranthery as a solution to the demands for pollen as food and for pollination-legitimate flower visitors reject flowers without feeding anthers. Plant Biol., https://doi.org/10.1111/plb.12609

Milet-Pinheiro, P., Schlindwein, C. (2009) Pollination in Jacaranda rugosa (Bignoniaceae): euglossine pollinators, nectar robbers and low fruit set. Plant Biol. 11, 131-141

Ministério do Meio Ambiente (MMA) (2014). Portaria No 443, de 17 de Dezembro de 2014. Disponível em: $<\mathrm{http}$ ://www.mma.gov.br. Acesso em 26/02/2014

Myers, N., Mittermeier, R.A., Mittermeier, C.G., Fonseca, G.A.B., Kent, J. (2000) Biodiversity hotspots for conservation priorities. Nature 403, 853-858

Nunes-Silva, P., Hrncir, M., Imperatriz-Fonseca, V.L. (2010) A polinização por vibração. Oecol. Aust. 14, 140-151

Pinto, C.E., Schlindwein, C. (2014) Pollinator sharing and low pollen-ovule ratio diminish reproductive success in two sympatric species of Portulaca (Portulacaceae). Stud. Neotrop. Fauna Environ. 50 (1), 4-13

Potts, S., Vulliamy, B., Roberts, S., O’Toole, C., Dafni, A., Ne'eman, G., Willmer, P. (2004) Nectar resource diversity organises flower-visitor community structure. Entomol. Exp. Appl. 113, 103-107

R Core Team (2015). R: A language and environment for statistical computing. R Foundation for Statistical Computing, Vienna, Austria. URLhttps://www.R-project.org

Ramos, A.M., Santos, L.A.R., Fortes, L.T.G. (Orgs.) (2009) Normais Climatológicas do Brasil (1961-1990). Instituto Nacional de Meteorologia. Brasília, DF. 465p

Rathcke, B., Lacey E. P. (1985) Phenological patterns of terrestrial plants. Annu. Rev. Ecol. Syst. 16, 179-214

Renner, S. (1983) The wide spread occurrence of anther destruction by Trigona bees in Melastomataceae. Biotropica 15, 251-256

Rodger, J.G., van Kleunen, M., Johnson, S.D. (2013) Pollinators, mates and Allee effects: the importance of self-pollination for fecundity in an invasive lily. Funct. Ecol. 27, 1023-1033

Roulston, T.H., Goodell, K. (2011) The role of resources and risks in regulating wild bee populations. Annu. Rev. Entomol. 56, 293-312

Santos, A.P.M., Romero, R., Oliveira, P.E.A.M. (2010). Biologia reprodutiva de Miconia angelana (Melastomataceae), endêmica da Serra da Canastra, Minas Gerais. Rev. Bras. Bot. 33, 333-341
Santos, A.P.M., Fracasso, C.M., Santos, M.L., Romero, R., Sazima, M., Oliveira, P.E.A.M. (2012) Reproductive biology and species geographical distribution in the Melastomataceae: a survey based on New World taxa. Ann. Bot. 110, 667-679

Sazima, I., Sazima, M. (1989) Mamangavas e irapuás (Hymenoptera, Apoidea): visitas, interações e conseqüências para polinização do maracujá (Passifloraceae). Rev. Bras. Entomol.33, 109-118

Schlindwein, C., Wittmann, D., Martins, C.F., Hamm, A., Siqueira Filho, J.A., Schiffler, D., Machado, I.C. (2005) Pollination of Campanula rapunculus L. (Campanulaceae): how much pollen flows into pollination and into reproduction of oligolectic pollinators? Plant Syst. Evol. 250, 147-156

Schlindwein, C., Westerkamp, C., Carvalho, A.T., MiletPinnheiro, P. (2014) Visual signalling of nectaroffering flowers and specific morphological traits favour robust bee pollinators in the mass-flowering tree Handroanthus impetiginosus (Bignoniaceae). Bot. J. Linn. Soc. 176, 396-407

Schmitt J. (1983) Density-dependent pollinator foraging, flowering phenology, and temporal pollen dispersal patterns in Linanthus bicolor. Evolution 37, 1247-1257.

Silberbauer-Gottsberger, I., Vanin, S.A., Gottsberger, G. (2013) Interactions of the Cerrado palms Butia paraguayensis and Syagrus petraea with parasitic and pollinating insects. Sociobiology 60 (3), 306-316

Slaa, E.J., Sánchez Chaves, L.A., Malagodi-Braga, K.S., Hofstede, F.E. (2006) Stingless bees in applied pollination: practice and perspectives. Apidologie 37, 293-315

Stein, K., Hensen, I. (2011) Potential pollinators and robbers: a study of the floral visitors of Heliconia angusta (Heliconiaceae) and their behaviour. J. Pollin. Ecol. 4 (6), 39-47

Stephenson, A. G. 1982. When does outcrossing occur in a mass-flowering plant? Evolution 36, 762-767

Tezuka, T., Maeta Y. (1995) Pollen robbing behaviors observed in two species of introduced stingless bees (Hymenoptera, Apidae). Jpn. J. Entomol. 63 , 759-762

Vaughton, G., Ramsey, M. (2010) Pollinator-mediated selfing erodes the flexibility of the best-of-bothworlds mating strategy in Bulbine vagans. Funct. Ecol. 24, 374-382

Wilcock, C., Neiland, R. (2002) Pollination failure in plants: why it happens and when it matters. Trends Plant Sci. 7, 270-277

Wille-Trejos, A. (1963) Behavioral adaptations of bees for pollen collecting from Cassia flowers. Rev. Biol. Trop. 11 (2), 205-210 